a spring phytoplankton and a summer zooplankton gathering.). Prof. Benjamin Moore has recently found ${ }^{3}$ a noteworthy change in the chemical reaction of the sea water round our coasts at different seasons of the year, no doubt in co-relation with the development of the plankton organisms. In spring (April) the water, not only on the shore, but out at sea, is acid to phenolphthalein, while in summer (August) it is distinctly alkaline to the same indicator. This change signifies an enormous conversion of carbon in the inorganic into carbon in organic form, a turn-over of colossal extent amounting to between 20,000 and 30,000 tons of carbon per cubic mile of sea water, or, if we think of the carbon as being in the bodies of living organisms, then the weight of these organisms will amount to about ten times that quantity of carbon in the cubic mile--or, if we imagine it occupying the deepest part of the Irish Channel, say, 300,000 tons of organisms per strip of water ten miles long by one mile broad and eighty-eight fathoms deep, all supplied with their necessary carbon from the carbon dioxide present in the sea water in spring.

Thus we can be led on from the simple observation of minute organisms on the beach to some of the greatest problems in the metabolism of the ocean; but the naturalist investigator need not necessarily venture out to sea in his quest. There is plenty of useful work to be done on the beach in carefully examining with the microscope the various deposits, such as sand and mud, found between tide marks, not once for all, but periodically, so as to determine the nature. of the minute animals and plants, their relative abundance, and their variations, seasonal or otherwise, in quantity and character throughout the year. We know that some of these organisms, although individually insignificant, may exist in such quantities as to discolour the sands or the sea water, and even give rise to plagues amongst shellfish and other more directlv valuable animals. Invasions of this kind, due to Dinoflagellata closely allied to our Amphidinium, are known to have appeared in America and in Australia, and possibly elsewhere. It is work worthy of the best endeavours of some of the younger botanists and zoologists of the Linnean Society, who have ready access to the coast, to try to extend our knowledge of the range and life conditions of some of those remarkable organisms-organisms which not only present scientific problems to the field naturalist, the cytologist, the experimental biologist, and biochemist, but, moreover, may well, from their vast numbers and sudden changes, have a profound effect upon the metabolism of the ocean, and so upon the prosperity of sea-fisheries.

\section{THE UNIVERSITY OF BRISTOL IN RELATION TO AGRICULTURE.}

THE University of Bristol, the youngest of our universities, has made it evident that it intends to play an active part in the development of agricultural education and research. Some two years ago the University associated with itself the Royal Agricultural College, Cirencester, for purposes of higher education in agriculture, and arrangements for the granting of degrees in that subject are now being completed.

The Board of Agriculture and Fisheries has recently notified its intention of making an annual grant of $500 l$. to the college to enable it to provide for research on questions relating to forestry for the west of England area.

3 Ir: the course of a Percy-Sladen Trust research upon the nutrition of maine animals, the detailed results of which will be published at an early vai $\leqslant$.

NO. 2248, VOL. 90]
The University has also recently associated with itself the National Fruit and Cider Institute, which was established at Long Ashton, near Bristol, in 1903, to carry on investigations on fruit culture and cidermaking. This institution has been supported since its establishment by annual grants from the Board of Agriculture and Fisheries, the county councils of Devon, Gloucester, Hereford, Monmouth, Somerset, and Worcester, and the Bath and West of England Agricultural Society. Its association with the University is the result of an offer on the part of the Board of Agriculture and Fisheries to the latter of an annual grant approximating to 250ol. to provide for the establishment of one of the agricultural research institutions contemplated by the Board in connection with the grant from the Development Fund available for the promotion of agricultural research.

The special subject of research allotted to Bristol is that of fruit-growing, including the practical treatment of plant diseases. The offer of the Board was conditional on the National Fruit and Cider Institute being made the centre at which the work was to be carried on. In connection with the scheme a capital expenditure of $10,000 l$. has been estimated to be necessary. Of this sum the Development Commissioners intimated their willingness to provide 50 per cent., provided that the remaining half was raised locally. Largely owing to the efforts of the Rt. Hon. Henry Hobhouse, chairman of the Somerset County Council, the necessary money has been subscribed. The expenditure is required for the purchase of land and the erection and equipment of laboratories and other buildings at Long Ashton. A department of agricultural and horticultural research has thus been created, Mr. B. T. P. Barker, director of the National Fruit and Cider Institute, being appointed head of the department and professor of agricultural biology in the University. Towards the upkeep of the department the University is contributing an annual sum of $300 l$., the income of a gift from the late Lord Winterstoke for the purpose of agricultural research; and the income from other sources, including county council grants, is about $1500 l$.

The department of chemistry in the University is also taking part in the work. In the biochemical laboratory, investigations on the tannins of cider are proceeding in connection with the fruit research work. A special grant from the Development Fund for the continuation of investigations on the chemistry of Cheddar cheese, which have been carried out during the past two years by Dr. Nierenstein, has been promised. This work was begun in the first place at the request of the Somerset County Council, a grant for the purpose being given by that body.

The Board of Agriculture and Fisheries also proposes to make the University the centre for a group of the western counties in connection with its scheme for the provision of technical advice to farmers. The group will probably include Gloucester, Hereford, Somerset, Wiltshire, and Worcester, and possibly one or two other adjoining counties for special purposes. An annual sum of roool. is provided by the Board for this work. Under this scheme investigations on problems of local agricultural importance will be undertaken. In this connection reference may be made to the work on the "teart" or scouring land of Somerset, which has already been conducted by Mr. C. T. Gimingham for the past two years.

The following appointments to the staff of the Department of Agricultural and Horticultural Research have already been made:-Mr. A. H. Lees as plant pathologist, Mr. C. T. Gimingham as agricultural chemist, and $\mathrm{Mr}$. Otto Grove, for some time assistant to Dr. Alf. Jörgensen, of Copenhagen, as 
œnologist. A mycologist will be appointed in due course. In the biochemical laboratory Mr. Arthur Geake has been appointed research assistant to Dr. Nierenstein for the investigations on the chemistry of Cheddar cheese, and Mr. C. W. Spiers research assistant for the cider tannins investigation.

\section{UNIVERSITY AND EDUCATIONAL INTELLIGENCE.}

CAmbridge. - The council of St. John's College has offered to the University $500 l$. as a contribution to the equipment of the Solar Physics Observatory on its installation in Cambridge.

The special board for biology and geology has adjudged the Walsingham medal for 1912 to E. D. Adrian, for his essay entitled, "On the Transmission of Subnormal Disturbances in Normal and in Incompletely Recovered Nerve."

The Walsingham medal for $\mathrm{Ig}_{3} 3$ is to be awarded for an essay embodying the results of original research on any botanical, geological, or zoological subject, zoology being understood to include animal morphology and physiology.

K. R. Lewin has, with the approval of the ViceChancellor, been appointed assistant to the Quick professor of biology, in succession to Mr. C. Strickland, who has resigned the post.

The General Board of Studies has appointed W. B. Hardy a University lecturer in physiology from January I, 1913, until September 30, r9I7.

$N$. Cunliffe has been appointed to the studentship in medical entomology lately held by $\mathrm{G}$. Merriman.

It is proposed to confer the degree of Master of Arts, honoris causa, upon Sir Arthur Thomas QuillerCouch, King Edward VII professor of English literature, and upon Dr. John Read, assistant to the professor of chemistry.

OXFORD.- On November 26 the preamble of the statute abolishing the existing division into orders of the elected members of council was moved in Congregation by Prof. Gellart, and supported by the warden of Keble. It was opposed by Prof. Gotch and Mr. Ball, and rejected by 87 to 105. The statute will probably be reintroduced in another form.

At the same meeting of Congregation the preamble of a statute amending the constitution of Congregation by abolishing the qualification of residence, and providing that in future that body shall consist only of the teaching and administrative elements in the University and colleges, was moved by Prof. Geldart, and, in spite of the opposition offered by the master of Balliol and Mr. Ball (by the latter on the ground that it provided for the safeguarding of vested interests), was carried by 100 to 79 . An objection felt in many quarters to this enactment is based on the fact that it will disfranchise such persons as those graduates engaged in scientific or other research who do not happen to be employed in teaching or administration within the University. It is understood that no amendment to admit such persons will be possible under the preamble as now carried.

THE office of Vice-Chancellor of the University of Sheffield, vacant through the retirement of Sir Charles Eliot, has been accepted by $\mathrm{Mr}$. H. A. L. Fisher, fellow and tutor of New College, Oxford.

Among the bequests of Mrs. A. M. Jones (widow of Prof. Tom Jones, of Manchester, surgeon), who died on October 30 , are soool. to the Victoria University, Manchester, in augmentation of the endowment of the Prof. Tom Jones memorial scholarship, and NO. 2248 , VOL. 90] 500k. to the University College of Wales, Aberystwith, as an endowment for promoting the study of surgery.

AT the annual meeting of the court of governors of the University of Wales on November 22 a resolution, moved by Sir Isambard Owen, that steps be taken to secure representation in Parliament for the Welsh University was carried by seventeen votes to twelve. In moving his resolution, Sir Isambard said that if university representation is to be continued there is no doubt that the younger universities will all be agitating for privileges with the older universities, and there is a danger that Parliament will pool these younger universities with only one representative for each group. He held that it is necessary that the Welsh University should not be pooled with, say, Birmingham or Bristol, because the Welsh University is national and possesses distinct interests.

THE governing body of the Imperial College of Science and Technology has decided to combine all the mathematical work of the Imperial College, and of its integral parts, viz. the Royal College of Science, the Royal School of Mines, and the City and Guilds (Engineering) College, into one department, and to place the supervision of this department under a chief professor of mathematics. A special joint committee of the governing body and of the delegacy of the City and Guilds College has now been constituted in connection with the selection of a suitable individual for appointment to the chair. It is the intention of the governing body to make the appointment from a date during the current session, so as to enable the new organisation to be perfected before October next, when the work of session $1_{91} 3^{-14}$ begins.

THE proceedings at the congress of the fifty-three universities of the Empire, which took place in London last July, were described in articles published in the issues of Nature for June 13 and July II last (vol. Ixxxix., pp. 385 and 477). The official record of the proceedings has now been published for the congress by the University of London Press, Messrs. Hodder and Stoughton, London, as a volume of 464 pages, the price of which is 1os. net. If the congress meets, as proposed, at recurring intervals of five years, reports such as that now avaiiable will serve excellently to record the steps in the future development of university ideals. Not only are the papers read at the congress by experts on university education included, but the speeches made at the various meetings are also reported.

THE calendar for the session I912-13 of University College, London, which is now available, is full of interesting particulars of the manifold activities of this important constituent college of the University of London. The list of original papers and other publications from the various departments of the college, since the dean's report in the preceding calendar, runs to sixteen pages, and an examination of it shows that each faculty recognises fully the vital importance of research work. It is worthy of note that the new chemical laboratories have been begun, and will be ready in about a year's time. The equipment of the faculty of medical sciences has been improved by the provision of the new pharmacology laboratories by Mr. Carnegie. These laboratories will shortly be opened. The total number of students in the college during the session $1911-12$ was $1679-1031$ men and $6 \Delta x$ women. Engaged in post-graduate and research work there were 286 men and II women. The faculty of science was chosen by 175 men and 135 women, and engineering was taken up by I04 men.

THE Department of Agriculture and Technical Instruction for Ireland has arranged that a limited number of scholarships and of teacherships-in-training, 